\title{
Correction: Has the athlete trained enough to return to play safely? The acute:chronic workload ratio permits clinicians to quantify a player's risk of subsequent injury
}

Blanch P, Gabbett TJ. Has the athlete trained enough to return to play safely? The acute:chronic workload ratio permits clinicians to quantify a player's risk of subsequent injury. Br J Sports Med 2016;50:471-5. doi:10.1136/bjsports-2015-095445

In the section 'Understanding relative workloads can provide clinicians and coaches with an 'absolute injury risk' and it changes week to week', second paragraph, the last sentence should read: We have included the external (balls bowled) and internal (session $\mathrm{RPE}=$ minutes $\times$ self-reported exertion) load measures from the cricket paper, the total running load data from the rugby league paper (but have excluded the data taken on very high training loads as an athlete who has been injured is unlikely to have a high training load) and the total running load and highspeed running load from the Australian football paper.

(C) Author(s) (or their employer(s)) 2019. No commercial re-use. See rights and permissions. Published by BMJ.

Br J Sports Med 2019;53:e6. doi:10.1136/bjsports-2015-095445corr1

D Check for updates 